\title{
USE OF MORPHOLOGICAL CHARACTERS TO IDENTIFY CASSAVAMOSAIC DISEASE AND CASSAVA BACTERIAL BLIGHT RESISTANCE
}

\author{
F.O. SOYODE ${ }^{1,2}$ and O.J. OYETUNJI ${ }^{1}$ \\ ${ }^{1}$ Department of Botany and Microbiology, University of Ibadan, Nigeria \\ ${ }^{2}$ Cassava Improvement Programme, International Institute of Tropical Agriculture (IITA), Ibadan, Nigeria
}

(Received 17 May, 2008; accepted 21 August, 2009)

\begin{abstract}
Diseases are among the major constraints that prevent cassava's (Manihot esculenta L.) optimum yield. Both the improved cassava breeds and local germplasms in the International Institute of Tropical Agriculture, Ibadan expressed wide genetic variability in morphological characters and diseases resistance. The current criteria for disease resistant varieties among the cassava cultivars appeared to be cumbersome. Attempts were made to identify and classify the clones based on the morphological traits expressed by the improved breeds and the landraces. Genotypes were scored for resistance to cassava mosaic disease (CMD) and cassava bacteria blight (CBB) attacks in the field. It was evident that identification of cassava genotypes using morphological characters is reliable. Some genotypes were resistant to CMD and CBB attack. It was found that pigmentation and level of branching confers resistance to cassava against CMD and CBB attack. CBB incidence was highly correlated $(\mathrm{P}<0.001)$ with both pith and hardwood thickness. The negative relationship between CBB severity and sprouting was very significant $(\mathrm{P}<0.001)$ for 3,6 , and 9 days after planting (DAP). CMD incidence showed a high correlation $(\mathrm{P}<0.001)$ with $\mathrm{CMD}$ severity. A similar result was observed in the relationship between CBB incidence, showing a strong correlation $(\mathrm{P}<0.001)$ with $\mathrm{CBB}$ severity.
\end{abstract}

Key Words: Cassava germplasms, CBB, CMD, Manihot esculenta

\section{RÉSUMÉ}

Les maladies sont parmi les principaux contraintes qui empêchent le rendement optimal du manioc. Les cultivars améliorés de manioc (Manihot esculenta L.) et le germplasms local de l'Institut International d'Agriculture Tropicale, Ibadan avaient exprimés une importante variabilité génétique des caractéristiques morphologiques et de résistance aux maladies. Les présentes critéristiques pour les variétés résistantes pour les cultivars de manioc semblent etre encombrants. Les tentatives avaient été faites pour identifier et classifier les clones basés sur les caractéristiques morphologiques exprimées par les cultivars améliorées et les cultivars locaux. Les génotypes étaient évalués pour la résistance à la maladie de la mosaïque du manioc (CMD) et les attaques par la maladie de tâches bactériennes du manioc (CBB) dans le champ. Les données avaient montré que l'identification des génotypes de manioc en se servant des caractéristiques morphologiques est fiable. Certains génotypes étaient résistants aux attaques de CMD et CBB. Il avait été constaté que la pigmentation et le degré de ramification confèrent au manioc une résistance contre les attaques de CMD et CBB. L'incidence de CBB était très significativement corrélée $(\mathrm{P}<0,001)$ avec aussi bien la moelle que l'épaisseur du bois. La relation négative entre la sévérité du CBB et la germination était significative $(\mathrm{P}<0,001)$ pour 3,6 et 9 jours après la plantation (DAP). L'incidence de CMD avait montré une corrélation hautement significative $(\mathrm{P}<0,001)$ avec la sévérité du CMD. Un résultat similaire avait été observé dans la relation entre l'incidence du CBB, montrant une corrélation hautement significative $(\mathrm{P}<0,001)$ avec la sévérité du CBB.

Mots Clés: Germplasms du manioc, CBB, CMD, Manihot esculenta 


\section{INTRODUCTION}

Cassava serves as a major staple crop in the tropics and doubles as one of the primary sources of food and energy in the diet of several millions of people in Africa. Over $85 \%$ of cassava produced worldwide is consumed by human beings (Fauquet and Fargette, 1990 as cited by ISPP, 2003). Cassava needs efficient management to improve food security in sub-Saharan Africa (Dorosh, 1989). There is need to study and screen cassava genotypes so as to obtain those that can combine acceptable agronomic characters, pest and disease resistance with drought tolerance for these regions.

It has been observed that some of the improved varieties out-yield land races in Nigeria, particularly in some of the semi-arid areas (IITA, 1987/1988). The recent extension of cassava cultivation to semi-arid areas makes it even more imperative for conducting research on cassava to screen for varieties that are suitable for these areas and can as well combine high yield with resistance to major diseases and insect pests. Resistance to diseases seems to be multifaceted. The response phase usually includes accumulation of different compounds such as phytoalexins (de Armas et al., 2007).

The effects of diseases and pests on cassava are very complex and can lead to great loss in yield depending on their types, severity and cassava genotypes (ISPP, 2003). Diseases severely affect establishment of cassava cuttings. Cassava Mosaic Virus Disease, Cassava Bacteria Blight and Cassava Anthracnose are the most important diseases of cassava (IITA, 1990).

Cassava mosaic disease is known to be transmitted by a whitefly (Bemisia tabacii.Genn). The reduction in photosynthetic leaf area can cause up to $90 \%$ yield loss. However, the susceptibility of varieties is genetically governed and some resistant/tolerant clones have been obtained through hybridisation (Theberge, 1985; Allem and Hahn, 1991). Cassava Bacteria Blight is caused by Xanthomonas campestris $p v$ manihotis. Yield losses reported come up to $100 \%$ in cases of severe attack on susceptible varieties. Besides this, CBB causes scarcity of cassava planting material by destroying the stems and cassava is mainly propagated from stem cuttings (Roca, 1989; Osiru et al., 1992).

The severity and incidence are highly correlated with the amount of rainfall received (IITA, 1990). Disease control measures have been widely reviewed (Lozano and Booth, 1976; IITA, 1990).

The symptoms of what is now known as CMD were first reported more than 100 years ago in what is now known as Tanzania (Warburg, 1894 as cited by Thresh et al., 1994). The disease was later identified in many other countries of subSaharan Africa during the early decades of the $20^{\text {th }}$ century. It was particularly prevalent in GoldCoast (now Ghana), Nigeria, Cameroon, Madagascar and several of the former French colonial territories of West and Central Africa. Data on the effects of CMD on the growth and yield of cassava have been collected at different times and places on a wide range of cultivars (Thresh et al., 1994). However, majority of farmers in cassava growing regions have little or no knowledge of cassava diseases and, therefore, do practically little or nothing to control such diseases. Selection for cultivars that possess morphological traits that reduces the severity of these two diseases will have tremendous effect on cassava productivity in the humid tropics.

Therefore, the objective of this study was to identify cultivars that possess such traits which can assists both the cassava breeders and growers in the nearest future.

\section{MATERIALS AND METHODS}

The experiment was carried out in the field at IITA Experimental Station, Ibadan, which is situated at the Northern fringe of the tropical forest. Its mean annual rainfall is $1200 \mathrm{~mm}$; while mean monthly temperature is $26.6{ }^{\circ} \mathrm{C}$ and relative humidity is high. The plots (12 $\mathrm{m}$ x $8 \mathrm{~m})$ were ploughed and ridged at a distance of $1 \mathrm{~m}$ apart.

Cassava cultivars used consisted of improved breeds and the land races (local germplasm). Fourty eight cassava genotypes and 161 landraces were used in this study (Table 1). The stakes were planted $1 \mathrm{~m}$ by $1 \mathrm{~m}$ apart. The total experimental farm size used for the planting of the improved breeds was 1.21 ha and contained 48 genotypes. A total of 161 land race genotypes 
Relationship between cassava pigmentation and diseases resistance

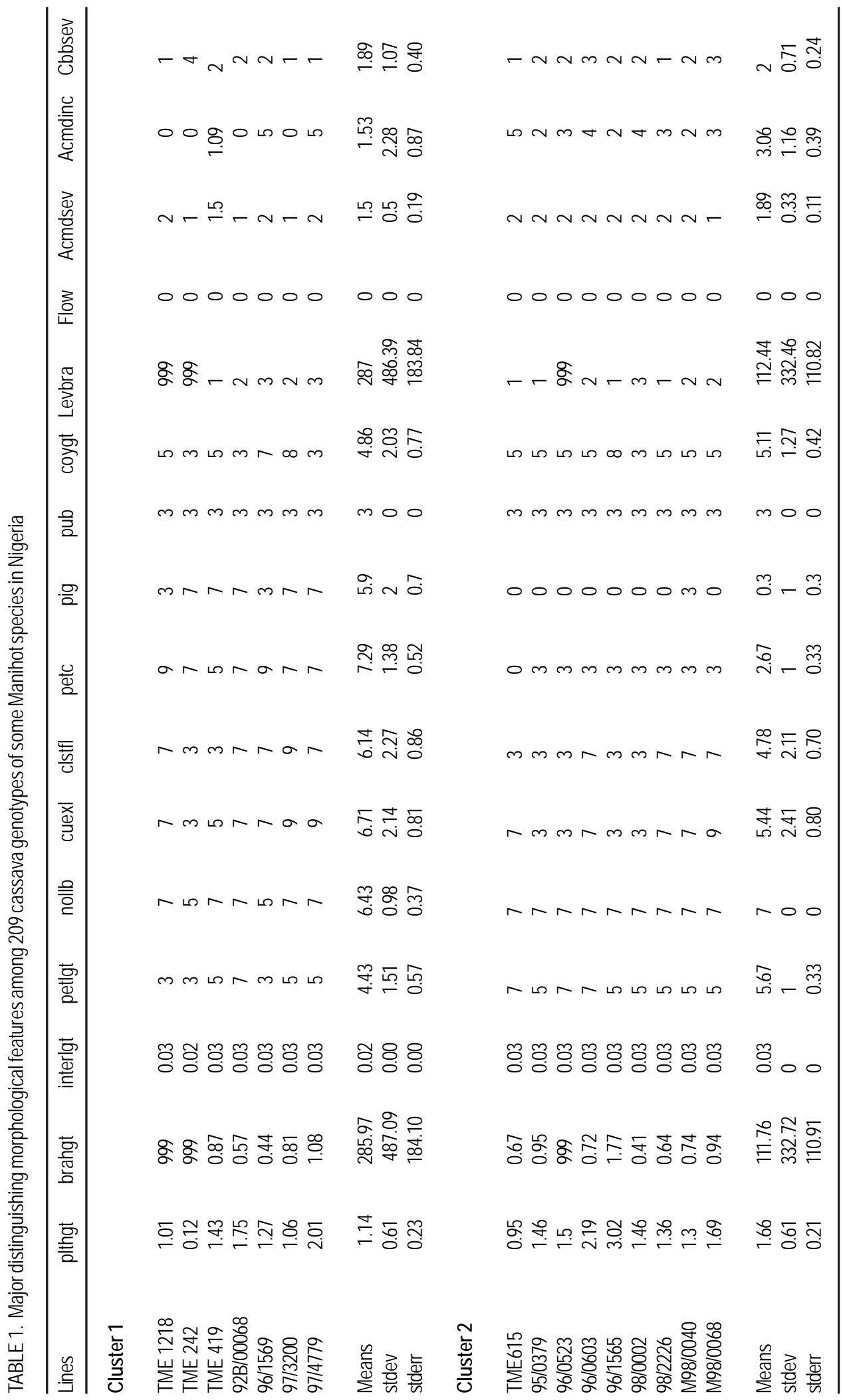




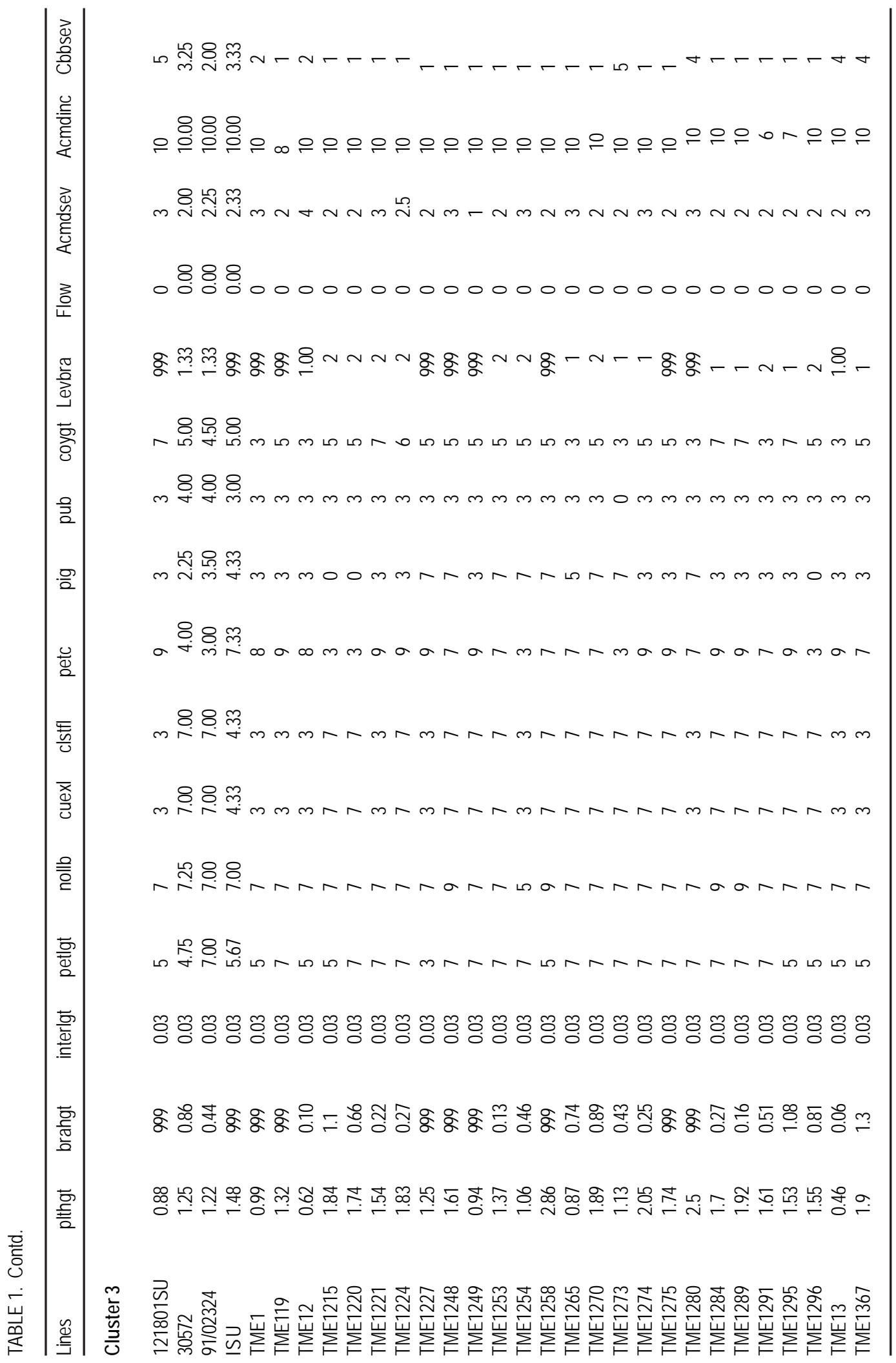




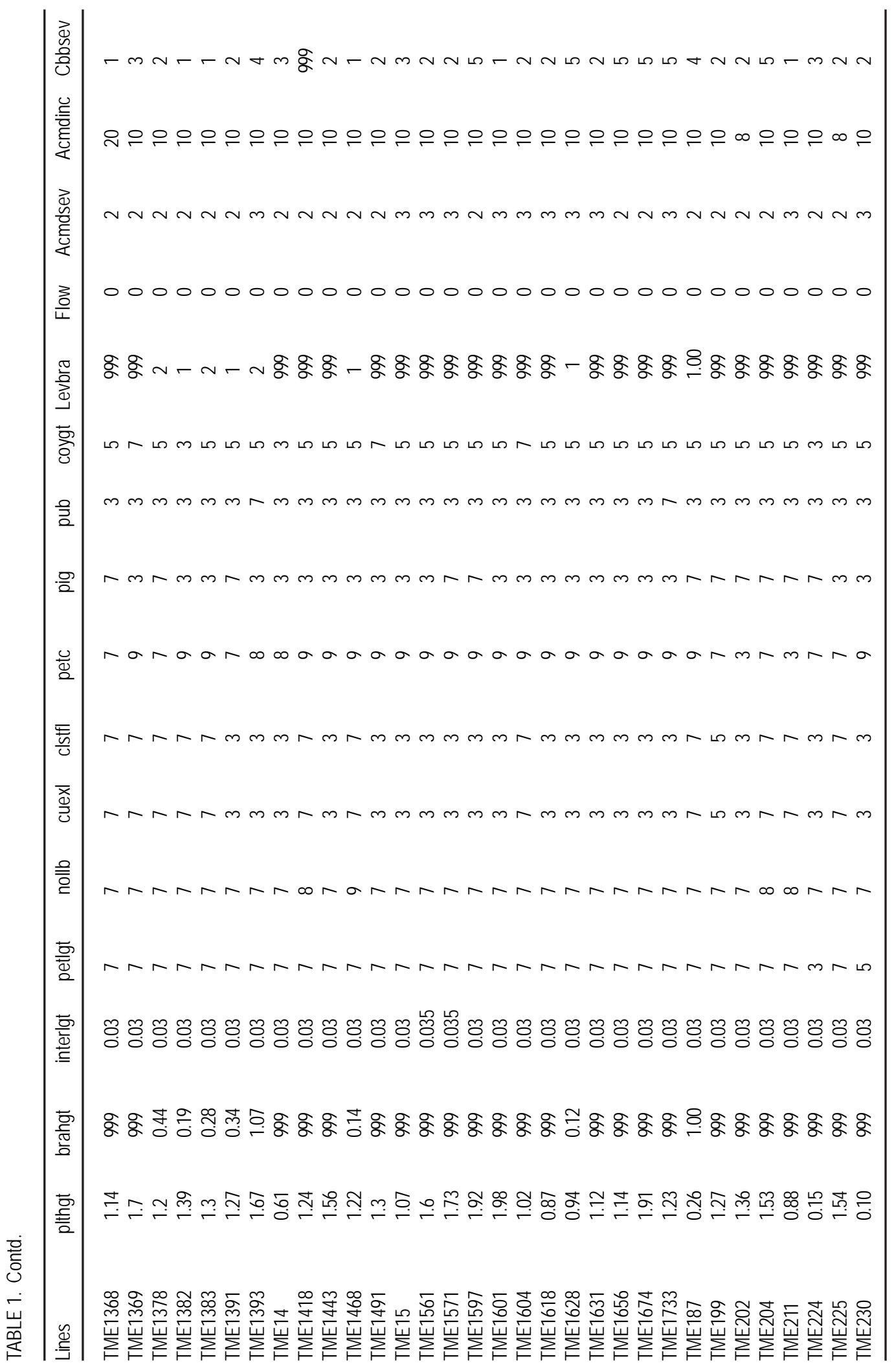




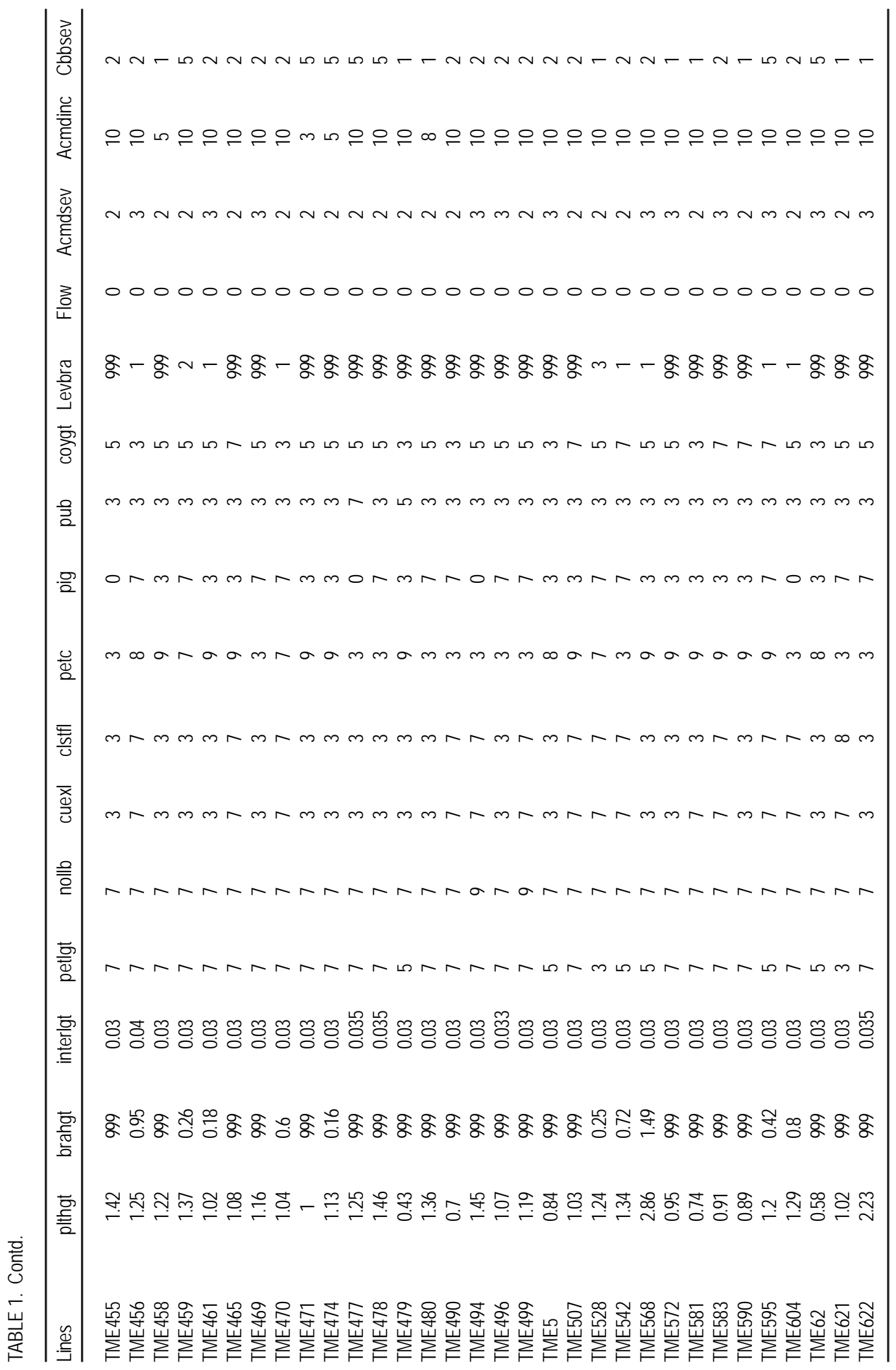


Relationship between cassava pigmentation and diseases resistance

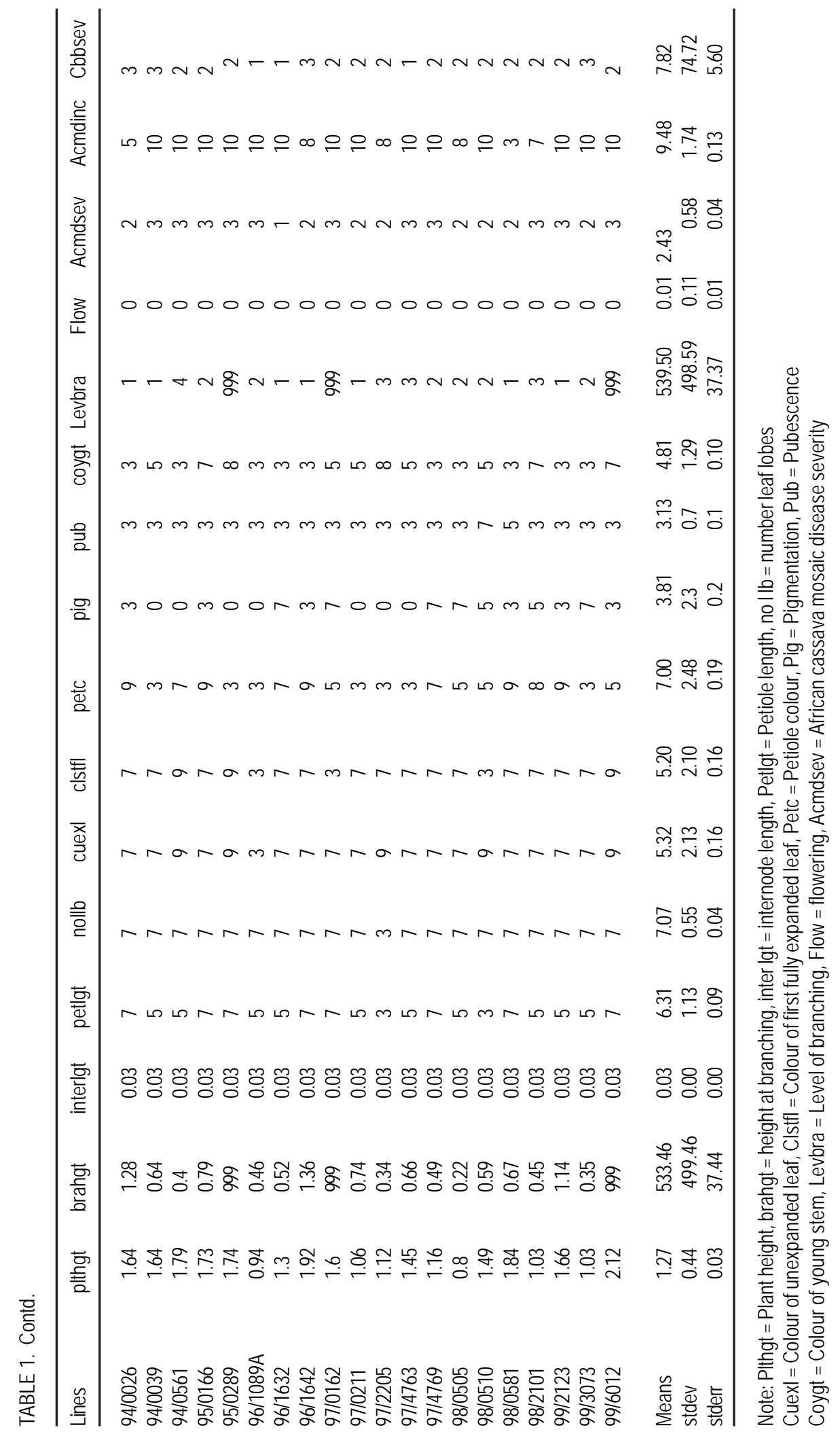


The data collected on cassava plants showed distinguishing morphological characters, which were subjected to cluster analysis from which a dendogram was drawn (Fig. 1). The distinguishing characters with the character codes are listed in Table 1 . The means and standard errors of the values of the characters in each cluster formed Table 1.

Within these groupings, genotypes were identified with distinguishing characters peculiar to the cluster. From the clusters formed from the dendogram, the means and standard error values were obtained.

The negative relationship between CBB severity and sprouting was only significant $(\mathrm{P}<0.001)$ for 3, 6 and 9 DAP. CMD incidence showed a highly significant correlation $(\mathrm{P}<0.001)$ with CMD severity,as did CBB incidence and CBB severity ( $r=0.73$ and 0.67 , respectively) (Table 2). Result indicate some genotypes showed severe (level 4) infestation to CBB with extensive leaf wilt and defoliations; while some showed very severe (level 5) infestation complete defoliation, stem die back, standing and die back of lateral roots (Plate 1). Some genotypes showed severe (level 4) infestation to CMD with a mosaic pattern on all leaves, leaf distortion and size reduction while some showed very severe (level 5) infestation with misshapen and twisted leaves and stunting of the whole plant (Plate 2).

\section{DISCUSSION}

Morphological characters have proved a useful tool in $M$. esculenta classification (Rogers and Appan, 1973; Maduakor and Lal, 1989). There are three major cluster groups as shown in the result (Table 1 ). In cluster 1 , the genotypes possessed the greatest amount of anthocyanin pigmentation with the shortest plant heights occurring in genotypes in clusters 1 and 3 . The genotypes in cluster 1 could, however, be distinguished from other clusters in their higher level of resistance to the CMD and $\mathrm{CBB}$. On the other hand, cluster 2 and 3 have some common features, for instance petiole length and colour of expanded leaves.

Plant heights of the genotypes of the three clusters could not lead to serious relationships with how the genotypes were classified, nor their performance or their disease resistance.

Morphological observations on characters such as plant heights, weight of tuberous root, girth of tuberous root, etc., were used by (Mathura et al., 1986) on varieties of cassava grown under agro-climatic conditions of West Tripura during four years to judge performance studies and variability. They noted that phenotypic variance was highest for all characters than genotypic variance, and yield was affected by all characters except the height of the plant. Also Maduakor and Lal (1989) concluded that neither the rate of increase in height nor final height attained was significantly affected by plant population. Six morphological parameters and tuberous root yield were used to eliminate stability parameters in 25 hybrids of cassava by Rajandran et al. (1987) over eighteen environments in Kerala State of India. None of the character was stable.

It is noteworthy, however, that it is difficult to precisely describe the morphological characteristics of cassava because of numerous genotypes and the diversity of ecological environments in which cassava is commercially grown. Hence, the action of environment on the genotype (variety) is always important.

Morphological characterisation of the plant area grouped as constants or variable characteristics, the constants are those typifying the taxon that is the species or variety (Onyilagha and Lowe, 1985). The variable characteristics are influenced by environmental conditions and can be considered as products of the action of the environment on the genotype.

The wide variability of the botanical characteristics indicates a high degree of intraspecific hybridisation. Thus, these genotypes are distinguishable by morphological characteristics such as pubescence, leaf and root characters and biotic stress within the clusters (Sree Kumari et al., 1988; Velayudhan et al., 1989). An example of the wide variability of the botanical characteristic upon which the genotypes are classified and grouped in clusters is seen in their different levels of disease resistance. For genotypes in cluster 1 , the mean value for CMD severity is $1.50 \pm 0.11$, making these genotypes 


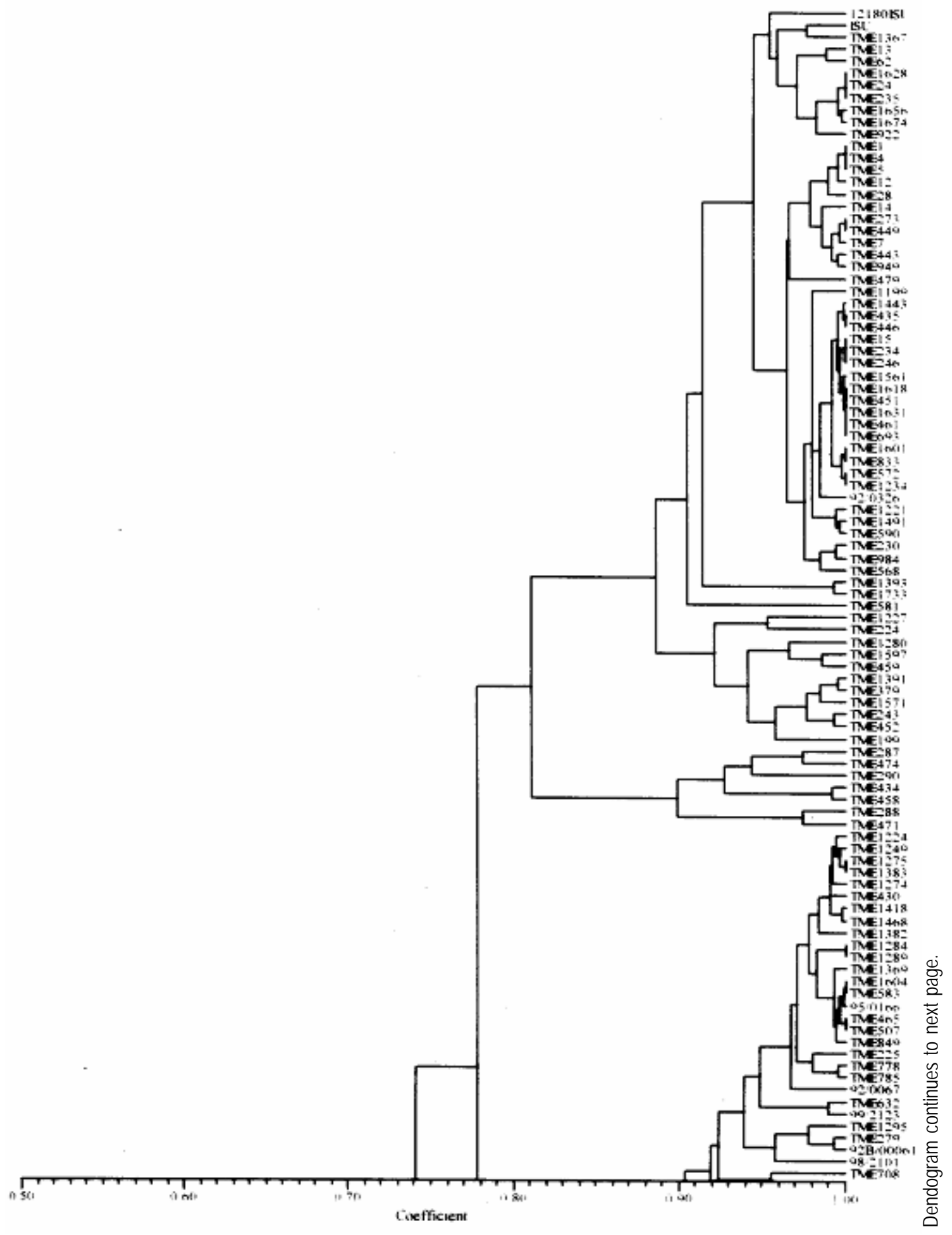




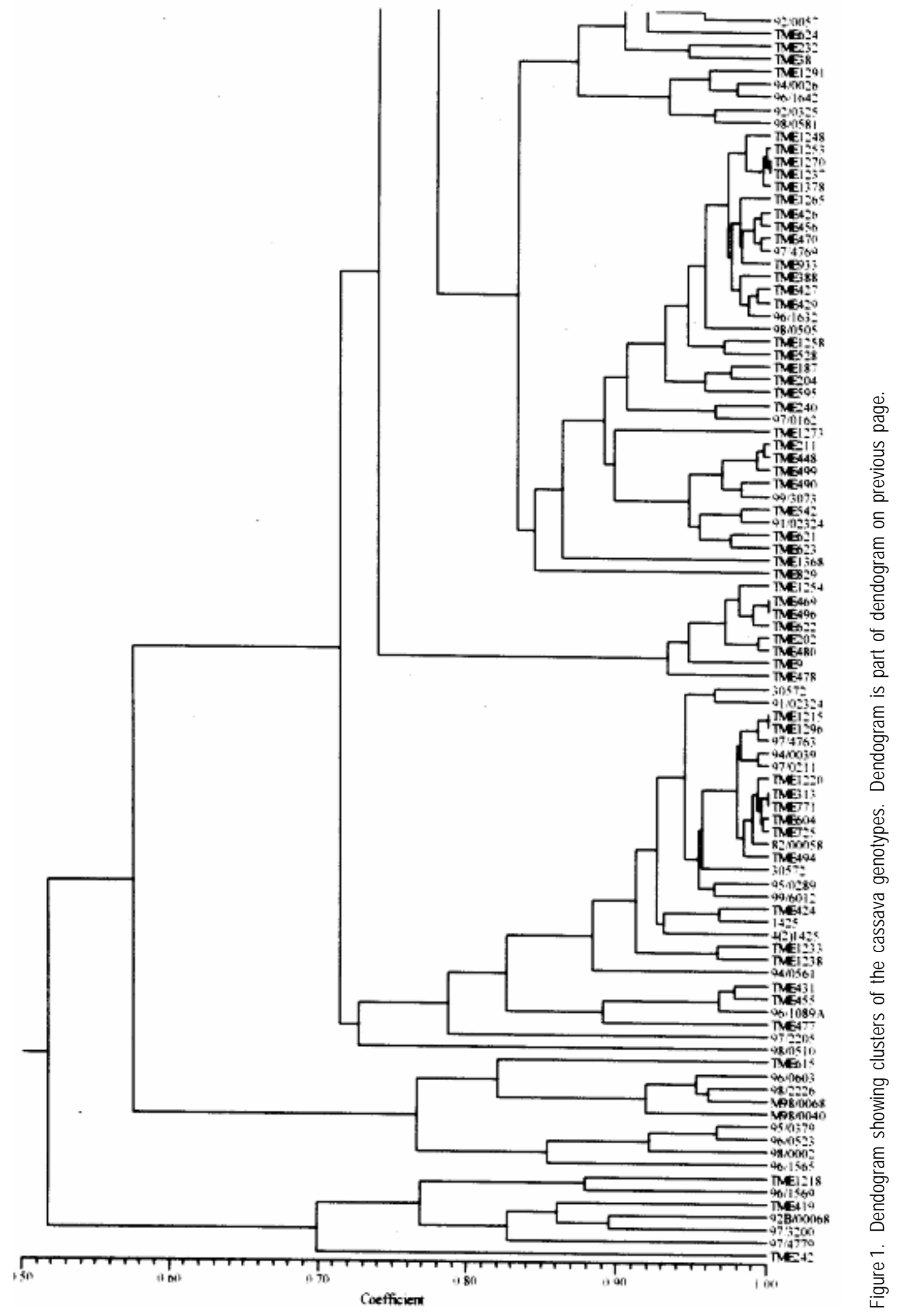




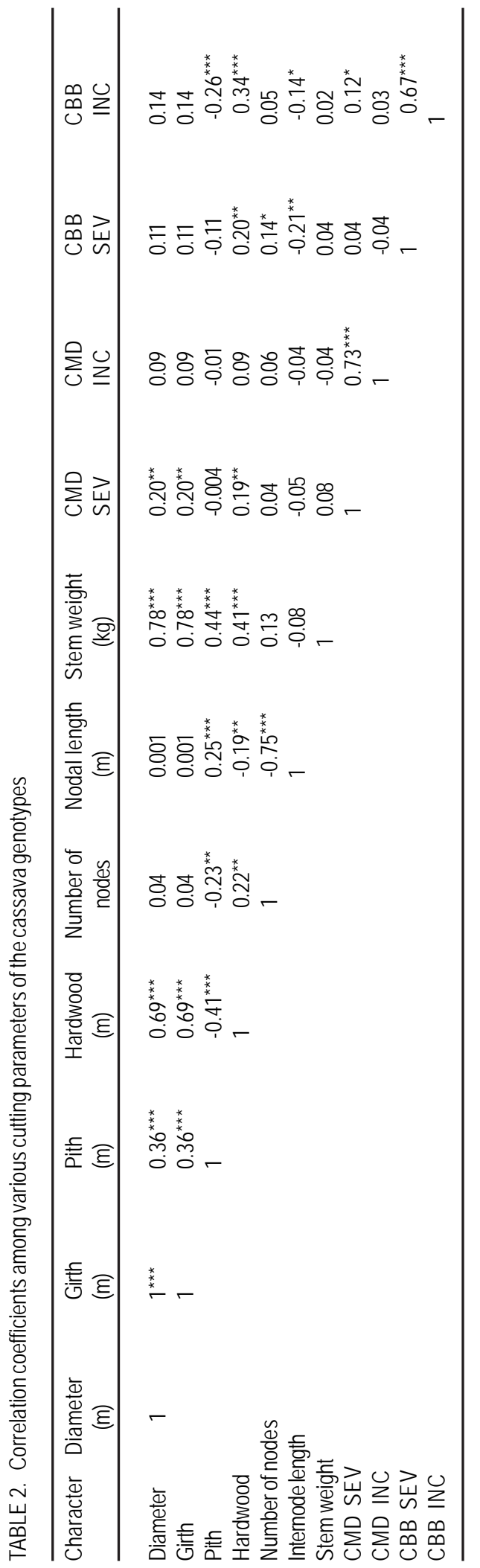
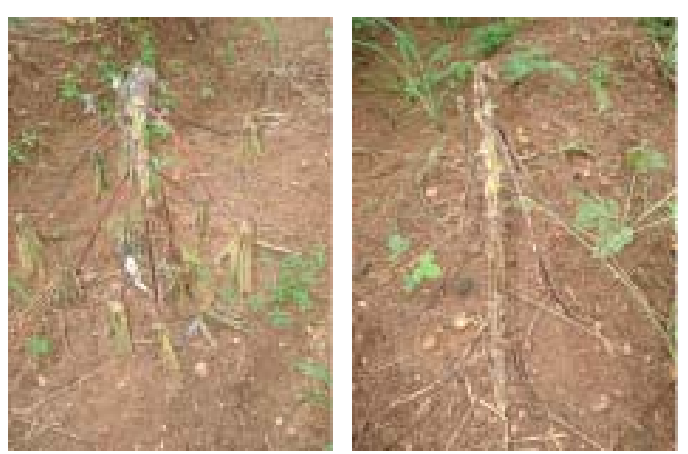

Plate1. Level of susceptibility of cassava genotypes to CBB disease; (a) severe (level 4) infestation with extensive leaf wilt and defoliations; (b) very severe (level 5) infestation, complete defoliation, stem die back, standing and die back of lateral roots.

a

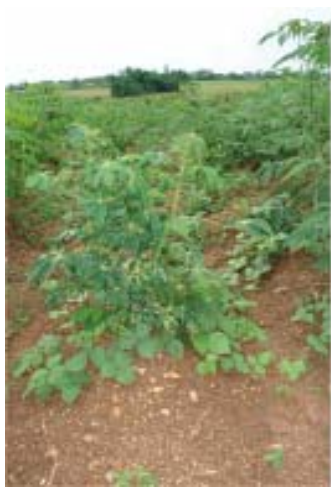

b

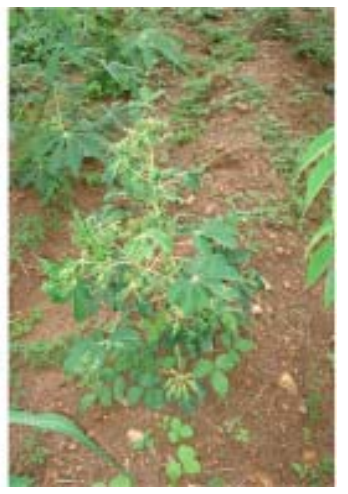

Plate 2. Level of susceptibility of cassava genotypes to CMD disease; (a) severe (level 4) infestation with mosaic pattern on all leaves, leaf distortion and size reduction; (b) very severe (level5) infestation with misshapen and twisted leaves and stunting of the whole plant.

the most resistant to African cassava mosaic disease. Genotypes in cluster 2 are less resistant to the disease with a mean value of $1.89 \pm 0.19$. Genotypes in cluster 3 are the least resistant to CMD and have a value of $2.43 \pm 0.04$. It is then clear from the foregoing that the genotypes are distinct based on this classification of their disease resistance and taking their wide variability (i.e. standard errors) into consideration. Genotypes in each cluster are distinctly different and not linked with genotypes in other clusters in any form of resemblance in their level of disease resistance. 
A similar observation was made for the level of resistance to the cassava bacteria blight disease in these genotypes. Genotypes in cluster 1 were more resistant to CBB $(1.86 \pm 0.24)$. Genotypes in cluster 2 were less resistant to $\mathrm{CBB}$ (2.00 \pm 0.40$)$. Genotypes in cluster 3 were the least resistant (7.82 \pm 5.60$)$.

This research work showed that genotypes in cluster 1 namely, TME 1218.96/1569. TME 419.92B/00068, 97/3200, 97/4779. TME 242 was the most resistant to ACMD and CBB attack. Genotypes that composed the cluster 2 include TME 615, 96/0603. 08/226. M98/0040, 95/0379.96/ 0523,98/0002 and 96/1565. While the least resistance to CMD and CBB attack was found in the remaining genotypes that composed cluster 3.

There were some morphological traits that enhanced the genotypes resistance to the diseases (CMD and CBB), for instance pigmentation (Lamb et al., 1989, Scalbert, 1991) and level of branching. Pigmentation and the level of branching were observed to be high for genotypes conferred with high resistance. Resistance attributed to genotype due to pigmentation can be explained by the anthocyanin content, which confers resistance. This is similar to the conclusion of de Armas et al. (2007) who worked on resistance of sugarcane to smut.

The antibacterial and antifungal properties of flavonoids (anthocyanin pigmentation) are well documented. Lamb et al. (1989) reported that flavonoids play a role in conferring disease resistance in many plants. Proanthocyanidins have been shown to accumulate when plants are infected and are believed to be defense compounds (Scalbert, 1991).

It should, therefore, be a welcomed idea when cassava genotypes of cluster 1 that is high in anthocyanin pigmentation and reputed to be resistant to CMD and $\mathrm{CBB}$ attack are used in areas where infestation of these diseases are high as they can perform well. A significant but negative correlation was observed between CBB incidences and sprouting on day 3, 6 and 9. After the 12th DAP, no relationship was found again, suggesting that with increase in growth, severity of the disease dropped and immunity probably built up. Otim-Nape et al. (2001), referred to the situation when plants recover from disease attack, showing no sign of symptoms at a later stage of growth as reversion.

\section{CONCLUSION}

Identification of cassava genotypes using morphological characters is reliable. This analysis is very economical and applicable in both small and large cassava plantations. Although there are other methods of identification and classification of cassava genotypes and germplasm accessions other than morphological characterisation, e.g. Isoenzyme analysis. Anthocyanin pigmentation confers immunity against CMD and CBB in cassava.

\section{REFERENCES}

de Armas, R., Santiago, R., Legaz, M.E. and Vicente, C. 2007. Levels of phenolic compounds and enzyme activity can be used to screen for resistance of sugarcane to smut (Ustilago scitaminea). Australasian Plant Pathology 36:32-38.

Dorosh, P. 1989. Economics of cassava in Africa. In: SARNA. pp. 371.

IBPGR. 1983. International Board for Plant Genetic Resources. pp. 459.

International Institute of Tropical Agriculture (IITA). 1987/1988 Annul Reports. pp. 175.

International Institute of Tropical Agriculture (IITA). 1990. Cassava in Tropical Africa: A Reference Manual, Ibadan, Nigeria. pp. 483. International Society for Plant Pathology (ISPP). 2003. Development of appropriate strategies to control cassava diseases in Ghana. Report of its Congress Challenge project on the management of cassava diseases in Ghana. pp. 158.

Lamb, C.J., Lawton, M.A., Dron, M. and Dixon, R.A. 1989. Signals and transduction mechanisms for activation of plant defense mechanisms. Plant and Cell 56:215-225.

Lozano, J.C. and Booth, R.H. 1976. Diseases of cassava (Manihot esculenta Crantz). Series DE-5, June, 1976. Centro Internacional de Agricultura Tropical. pp. 97. 
Maduakor, H.O. and Lal, R., 1989. Root System, top growth and yield of cassava (M. esculena Crantz) as affected by plant population and arid region. Journal of Root Crops 15:115 122.

Martin, F.N. 1988. Planting dates and morphology and growth of four sweet potato alones in Puerto Rico. University of Puerto Rico. Journal of Agriculture 72:437-444.

Mathura, R., Dhander, D, G., Varna, S.P. and 1986. Variability studies of cassava varieties on growth and yield under Tripura-conditions. Journal of Root Crops 12:25-28.

Onyilagha, J.C. and Lowe, J. 1985. The taxonomic position of yam cultivars 'ABI' studied by multivariate technique. Journal of Root Crops 11 (1 and 2):29- 36.

Osiru, D.S.O., Hahn, S.K. and Osonubi, O. 1992. Varietal response to drought stress in cassava. Proceedings of the $4^{\text {th }}$ symposium, ISTRC-AB. 1992. pp. 97-102.

Otim-Nape, G.W., Alicia, T. and Thresh, M. 2001. Changes in the incidence and severity of cassava mosaic virus disease, varietal diversity and cassava production in Uganda. Annals of Applied Biology 138:313-327.

Rajandran, P.G., Lakshmi, K.R. and Umikrishnan, M. 1987. Estimates the stability parameters in 25 hybrids of cassava (M. esculenta Crantz) at 18 environments in Kerala state. Journal of Root Crops 13:13-20.
Roca, W.R., Chavez, M.L., Marin, D., Arias, G. and Reyes, R. 1989. In vitro methods of germplasm conservation. Genome 31:813-817.

Rogers, D.S. and Appan, S.G. 1973. Flora neotropica, monograph Vol, 13. Manihot manihotoides (Euphorbiaceae) by Hafner press. New York, June 22, 1973.

Scalbert. A. 1991 Antimicrobial properties of tannins. Photochemistry 30:3875-3883.

Sree-Kumari MT, Abraham K, Ramanujam T 1988. The performance of cassava under shade. Journal of Root crops 14:43 - 52.

Tanksley, S.A. and Orton, T.J. (Eds.). 1983. Isoenzymes in plants genetics and breeding, parts IA and IB. Amsterdam: Elservier. pp. 296.

Theberge, R.L. 1985. Common Africa Pests and Diseases of Cassava, Yam, Sweet potato and cocoyam. International Institute of Tropical Agriclture, Ibadan, Nigeria. pp. 108.

Thresh, J.M., Otim-Nape, G.W. and Jennings, D.L. 1994. Exploiting resistance to African cassava mosaic virus Asp. Applied Biology 39:51-60.

Velayudhan, K.C., Muralidharam, V.K., Amalaaji, V.A., Thomas, T.A. and Soudhamini, P. 1989. Studies on the morphotypic variability, distribution and genetic divergence in an indigenous collection of greater yam (Dioscorea alata L.). Journal of Root Crop 15: 79-89. 